\title{
Pengaruh Model Pembelajaran Kooperatif Tipe Jigsaw Terhadap Hasil Belajar Kognitif Siswa Pada Materi Hukum Newton Kelas X MA Darul Muhajirin Praya
}

\author{
Kholia Urwati ${ }^{1}$, Nevi Ernita ${ }^{2}$, Yahdi ${ }^{3}$ \\ 1,2 Program Studi Tadris Fisika, FTK, Universitas Islam Negeri Mataram, NTB \\ ${ }^{3}$ Program Studi Tadris Kimia, FTK, Universitas Islam Negeri Mataram, NTB \\ e-mail: \\ ${ }^{1}$ kholiaurwati15@gmail.com
}

\begin{abstract}
.
The study aims to determine whether there is an effect of the type of jigsaw cooperative learning model on students cognitive learning outcomes on the subject matter of Newton's law in class X MA Darul Mubajirin Praya. This research is a quantitative study with a quasi-experimental type of research using the pretest-posttest control group design. The population in this study were all students of class X MA Darul Mubajirin Praya. The sample in this study were students of class X IPA2, namely the experimental class totaling 30 students and class X IPA1 amounting to 30 students in the control class selected by random sampling or random system. Data were collected using a multiple choice test method and essay. The data obtained were analyzed by statistical statistical analysis using the t-test. After analyzing the results of this study found that there are significant differences in cognitive learning outcomes between the experimental class using the Jigsaw type cooperative learning model and the control class using conventional learning models can be seen from the results of $t$-test calculations (tcount $=4,150>$ ttable $=$ 2,000). It can be seen that the use of Jigsaw cooperative learning models is better than conventional learning models in improving cognitive learning outcomes in Newton's law material..
\end{abstract}

Keywords: jigsaw type cooperative learning, cognitive learning outcomes, newton's law material

\begin{abstract}
ABSTRAK.
Penelitian bertujuan untuk mengetahui apakah terdapat pengaruh model pembelajaran kooperatif tipe jigsaw terhadap hasil belajar kognitif siswa pada pokok materi hukum Newton pada kelas X MA Darul Muhajirin Praya. Penelitian ini merupakan penelitian kuantitatif dengan jenis penelitian kuasi eksperimen dengan menggunakan desain pretest-postest control group desain. Populasi pada penelitian ini adalah seluruh siswa kelas X IPA MA Darul Muhajirin Praya. Sampel pada penelitian ini adalah siswa kelas X IPA ${ }^{2}$ yaitu kelas eksperimen berjumlah 30 orang siswa dan kelas X IPA ${ }^{1}$ berjumlah 30 orang siswa pada kelas kontrol yang dipilih dengan sistem random sampling atau secara acak. Data dikumpulkan dengan metode tes yang berbentuk pilihan ganda dan essay. Data yang didapatkan dianalisis dengan teknis analisis statistika yaitu menggunakan uji t-test. Setelah dianalisis hasil penelitian ini menemukan bahwa terdapat perbedaan hasil belajar kognitif yang signifikan antara kelas eksperimen yang menggunakan model pembelajaran kooperatif tipe jigsaw dengan kelas control menggunakan model pembelajaran konvensional dapat dilihat dari hasil perhitungan $\mathrm{t}$-test ( $\left.\mathrm{t}_{\text {hitung }}=4,150>\mathrm{t}_{\text {tabel }}=2,000\right)$. Hal ini dapat dilihat bahwa penggunaan model pembelajaran kooperatif tipe jigsaw lebih baik dengan model pembelajaran konvensional dalam meningkatkan hasil belajar ranah kognitif pada materi hukum newton.
\end{abstract}

Kata kunci: pembelajaran kooperatif tipe jigsaw, hasil belajar kognitif, materi hukum newton. 


\section{PENDAHULUAN}

Pendidikan merupakan suatu wadah atau sarana untuk meningkatkan hasil kualitas sumber daya manusia (SDM). Melalui pendidikan siswa mampu memperoleh pengetahuan dan pandangan yang luas serta keterampilan yang dibutuhkan untuk bekal hidup bermasyarakat (Nurul \& Suspriani, 2017). Pendidikan adalah usaha sadar dan terencana untuk mewujudkan suasana belajar dan proses pembelajaran agar siswa secara aktif mengembangkan potensi dirinya untuk memiliki kekuatan spiritual keagaman, pengendalian diri, kepribadian, kecerdasan, dan akhlak mulia, serta keterampilan yang diperlukan dirinya, masyarakat, bangsa dan terutama di lembaga sekolah.

Sekolah merupakan lembaga yang dicapai masyarakat sebagai tempat untuk menuntut ilmu. Seseorang yang pernah duduk dibangku sekolah akan memiliki wawasan, pengetahuan bahkan keperibadian yang lebih dari lainya. Oleh karena itu para orang tua yang menyekolahkan anaknya berharap kelak memiliki nilai lebih dari orang lain disekitarnya sehingga dapat dibanggakan. Begitu besar tanggung jawab sekolah sebagai lembaga pendidikan formal maka lembaga ini dituntut untuk memaksimalkan kegiatan pembelajaran yang ada didalamnya. Karena sekolah merupakan lembaga pendidikan, maka didalamnya terdapat proses belajar mengajar. Belajar dilakukan oleh siswa sedangkan mengajar dilakukan oleh guru.

Guru merupakan motor utama yang memiliki tanggung jawab langsung untuk menterjemahkan kurikulum ke dalam aktivitas pembelajaran dan bukan satu-satunya sumber utama pengetahuan. Hal tersebut dapat dilihat dari tugas dan peran guru, antara lain sebagai komunikator, fasilitator, motivator, model, evaluator, sumber belajar dan administrator. Berkaitan dengan tugas guru tersebut, maka seorang guru harus memiliki keterampilan dan kemampuan untuk melaksanakan kegiatan pembelajaran dengan sebaik-baiknya agar siswa mendapatkan hasil belajar yang optimal, termasuk dalam kegiatan pembelajaran di dalam kelas (Nurhaeni, 2011). Dalam setiap kegiatan selalu ada tujuan yang ingin dicapai, begitu juga dengan kegiatan pembelajaran yang merupakan bagian-bagian dari pendidikan ada tujuan yang ingin dicapai. Adapun tujuan yang ingin dicapai dalam proses pembelajaran salah satunya adalah hasil belajar kognitif.

Hasil belajar kognitif adalah perubahan perilaku yang terjadidi dalam kawasan kognisi, hasil belajar kognitif tidak merupakan kemampuan tunggal melainkan kemampuan yang menimbulkanperubahan perilaku dalam domain kognitif yang meliputi beberapajenjang atau tingkat (Nurhaeni, 2011). Hasil belajar yang ditinjau dari segi kognitifnya tergantung dari proses pembelajaran, yaitu bagaimana menggerakkan semua potensi yang dimiliki peserta didik terutama dari segi pemahamannya. Dari sekian unsur yang sangat menentukan kualitas proses pembelajaran salah satunya adalah model pembelajaran yang digunakanguru dalam menyampaikan materi pembelajaran. Selama ini kegiatan proses pembelajaran yang biasa dilakukan terkadang guru sebagai penyampai informasi kepada siswa kurang bisa menciptakan suasana belajar yang menarik dan kondusif.

Dari segi hasil belajar ranah kognitif ada 6 dimensi yaitu C1 (Mengingat). Mengingat yaitu usaha untuk mendapatkan kembali pengetahuan dari ingatan yang telah berlalu, baik yang baru saja didapatkan maupun yang sudah lama didapatkan. Mengingat merupakan dimensi yang berperan penting dalam proses pembelajaran yang berarti pemecahan masalah (problem solving). C2 (Memahami, memahami merupakan suatu yang berkaitan dengan membangun suatu pemahaman dari bermacam materi, bacaan dan berkomunikasi. Mengklasifikasikan akan muncul ketika seorang siswa berusaha mengenali pengetahuan yang merupakan anggota dari kategori pengetahuan tertentu. C3 (Menerapkan), menerapkan merupakan menerapkan, menentukan menemukan, melakukan dan mencetakkan yang meliputi seluruh prosedur yang dapat siswa selesaikan. C4 (Analisis), menganalisis atau analisis adalah sesuatu kegiatan yang mengkaji, membandingkan, dan menguji suatu permasalahan kegiatan yang berhubungan dengan kegiatan pembelajaran disekolah. C5 (Mengevaluasi), evaluasi merupakan suatu pengecekan dan 
mengkritisi suatu pengujian sesuatu yang tidak konsisten dari sebuah produk. Dimana mengkritisi merupakan suatu pemberian nilai terhadap suatu produk yang dapat dikatakan standar atau memasuki kriteria. C6 (Menciptakan), menciptakan merupakan sesuatu ranah kognitif yang mendorong siswa agar mampu menciptakan suatu produk dari pengalaman belajar siswa yang sudah dipelajari sebelumnnya (Gunawan, 2014).

Berdasarkan hasil observasi awal pada tanggal 7 Januari 2019, melalui wawancara yang telah dilakukan dengan siswa kelas X MA Darul Muhajirin Praya, mengenai pembelajaran fisika, rata-rata mengatakan sebagai berikut: (1) guru terlalu cepat dalam menjelaskan materi pembelajaran sehingga siswa kurang paham dalam mencermati materi, (2) rumus-rumus fisika yang terlalu banyak dan sulit dipahami, (3) guru hanya menerapkan satu model yaitu ceramah tanpa ada model yang bervariansi sehingga proses pembelajaran bersifat monoton tanpa ada model lain yang menjadi pembantu dalam kegiatan pembelajaran, (4) nilai rata-rata siswa setelah menerima pelajaran masih dikategorikan rendah atau belum mencapai nilai KKM yaitu 73 , sedangkan nilai rata-rata ulangan semester kurang dari 73 terdapat 24 siswa yang belum tuntas dengan persentase $66 \%$, sedangkan yang mendapat nilai diatas 73 yaitu 10 siswa yang dikatakan tuntas dengan nilai persentase $34 \%$. Oleh karena itu diperlukan adanya penggunaan model pembelajaran yang bervariansi, guru menciptakan ide-ide baru pada pembelajaran yang efektif dan menyenangkan sehingga siswa mampu memahami materi. Salah satu model pembelajaran yang biasa digunakan yaitu model pembelajaran kooperatif.

Model pembelajaran kooperatif adalah model pembelajaran yang dilakukan dengan membagi siswa menjadi beberapa kelompok atau kelompok kecil, yang terdiri dari 3-4 siswa. Hal ini atas dasar untuk lebih memudahkan siswa dalam memahami konsep-konsep yang sulit, apabila siswa dapat mendiskusikan masalah yang ada bersama teman kelompoknya. Selain itu model pembelajaran kooperatif merupakan salah satu alternatif bagi siswa untuk melakukan perbaikan pada proses pembelajaran melalui kerjasama antar teman sebaya untuk menyelesaikan masalah, dan mampu berpikir kritis terkait materi sehingga mampu meningkatkan hasil belajar siswa. Prinsip dasar pembelajaran kooperatif yaitu siswa membentuk kelompok kecil dan saling mengajari sesamanya untuk mencapai tujuan bersama, dalam pembelajaran inipun siswa pandai mengajari siswa yang kurang pandai tanpa merasa dirugikan (Syarifuddin, 2011). Salah satu tipe model pembelajaran kooperatif yang bisa digunakan untuk mengatasi masalah tersebut yaitu model pembelajaran kooperatif tipe jigsaw.

Model pembelajaran kooperatif tipe jigsaw merupakan model pembelajaran tipe pembelajaran kooperatif yang terdiri dari beberapa anggota dalam satu kelompok yang bertanggung jawab atas penguasaan materi belajar dan mampu mengajarkan bagaian tersebut kepada anggota lain dalam kelompoknya (Bahtiar, 2015). Setelah pembentukan kelompok dibagi lagi menjadi dua kelompok yaitu ada namanya kelompok ahli dan kelompok asal. Dimana masingmasing kelompok ahli berkumpul dan saling memberikan masukan untuk penyelesaian masalah tersebut dan saling tukar pemahaman. Setelah selesai kelompok ahli kembali ke kelompok asal untuk menjelaskan kepada teman-temannya sesuai keahlian yang mereka dapat.

Model pembelajaran kooperatif tipe jigsaw memiliki beberapa kelebihan antara lain: (1) Dapat meningkatkan hasil belajar,(2) meningkatkan daya ingat siswa,(3) siswa mampu berpikir kritis,(4) mendorong tumbuhnya motivasi intrinsik,(5) meningkatkan hubungan emosional terhadap temansebaya, (6) meningkatkan sikap siswa yang positif terhadap sekolah dan lingkungan sekitar,(7) meningkatkan sikap positif terhadap guru,(8) meningkatkan percaya diri anak (Oktafiani. Z, 2018).

Banyak penelitian yang sudah berhasil melakukan penelitian terhadap model pembelajaran kooperatif tipe jigsaw antara lain penelitian yang dilakukan oleh Ifa, M (2013) yang menyatakan bahwa penerapan model Pembelajaran kooperatif tipe jigsaw dapat meningkatkan hasil belajar siswa kelas X SMK Negeri 3 Boyolangu. Penelitian dari Trisianawati, E., Djudin, T., \& Setiawan, 
R. (2016) yang mengungkapkan bahwa model pembelajaran kooperatif tipe jigsaw berbasis macromedia flash dapat meningkatkan hasil belajar siswa pada materi hukum newton. Nurhaeni, Y. (2011) menyatakan bahwa pemahaman siswa pada konsep listrik melalui pembelajaran kooperatif tipe jigsaw mengalami peningkatan.

Berdasarkan uraian diatas peneliti tertarik untuk melakukan penelitian dengan judul "Pengaruh Model Pembelajaran Kooperatif Tipe Jigsaw Terhadap Hasil Belajar Kognitif Siswa pada Materi Hukum Newton, di kelas X MA Darul Muhajirin Praya. Agar siswa mampu berdiskusi atau belajar dengan teman sebaya yang dimana dapat menimbulkan inspirasi-inspirasi yang luas dengan cara berpikir, bertukar pendapat sehingga cocok dengan tujuan hasil belajar kognitif yaitu meningkatkan pengetahuan dalam memahami bentuk materi dan bentuk soal yang diberikan..

\section{METODOLOGI}

Jenis penelitian yang digunakan adalah penelitian quasi ekperimen. Penelitian quasi eksperimen diartikan sebagai metode penelitian untuk mencari pengaruh perlakuan terhadap yang lain dalam kondisi yang terkendalikan. Sedangkan pendekatan yang digunakan dalam penelitian ini yaitu pendekatan kuantitatif. Pendekatan kuantitatif digunakan untuk mencatat data hasil observasi. Pendekatan kuantitatif merupakan jenis data yang berbentuk angka, atau data kualitatif yang diangkakan seperti data dari kelas ekperimen dan kelas kontrol sebagai pembandingnya.

Adapun Populasi pada penelitian ini adalah peserta didik kelas X di MA Darul Muhajirin Praya dengan jumlah 64 orang peserta didik dan sampel yang dapat merujuk pada tabel dalam buku Metode Penelitian Pendidikan jumlah sampel yang diambil adalah 30 dengan taraf signifikasi 5\% (Sugiyono, 2017). Teknik simple random sampling. Teknik simple random sampling adalah teknik pengambilan anggota sampel dari populasi dilakukan secara acak tanpa memperhatikan strata yang ada dalam populasi itu (Prasetyo, B, 2016). Menurut Sugiyono bahwa pengambilan secara acak dapat dilakukan dengan random undian. Pada penelitian ini cara pengambilan secara acak akan dilakukan dengan undian. Dimana seluruh populasi diberikan nomor terlebih dahulu, selanjutnya melakukan penarikan undian sebanyak jumlah sampel yang diperlukan. Sampel pada penelitian ini adalah X IPA 1 sebagai kelas kontrol dan X IPA 2 sebagai kelas ekperimen.

Waktu dan tempat penelitian ini dilaksanakan pada bulan April 2019 di MA Darul Muhajirin Praya pada siswa kelas X semester II tahun pelajaran 2018/2019. Variabel bebas dalam penelitian ini adalah model pembelajaran kooperatif tipe jigsaw $(\mathrm{X})$ dan variabel terikat pada penelitian ini adalah hasil belajar kognitif siswa pada materi hukum newton (Y). Dimana variabel bebas dapat dipengaruhi oleh variabel terikat.

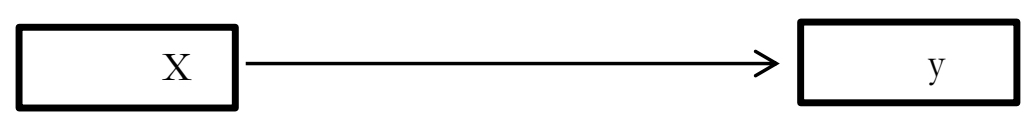

Gambar 1: pengaruh variabel $\mathbf{X}$ terhadap $\mathbf{Y}$

Adapun pola rancangan penelitian ini adalah.

Tabel 1. Pola Rancangan Penelitian

\begin{tabular}{lccc}
\hline \multicolumn{1}{c}{ Kelompok } & Pretest & Perlakuan & Posttest \\
\hline A (Eksperimen) & $\mathrm{T}_{1}$ & $\mathrm{X}_{1}$ & $\mathrm{~T}_{2}$ \\
\hline $\mathrm{B}$ (Kontrol) & $\mathrm{T}_{1}$ & $\mathrm{X}_{2}$ & $\mathrm{~T}_{2}$ \\
\hline
\end{tabular}


Keterangan:
A : Kelas Eksperimen
B : Kelas Kontrol
$\mathrm{T}_{1} \quad$ : Tes awal pada kelas kontrol dan kelas ekperimen
$\mathrm{T}_{2} \quad$ : Tes akhir pada kelas kontrol dan kelas ekperimen
X1 : Perlakuan model pembelajaran kooperatif tipe jigsaw
$\mathrm{X}_{2} \quad$ : perlakuan model konvensional atau metode ceramah (Sugiyono, 2010)

Instrumen tes yang digunakan adalah tes hasil belajar kognitif atau pengetahuan. Tes akan diberikan sebelum pembelajaran (prestest) dan sesudah seluruh kegiatan pembelajaran selesai (posttest). Soal yang digunakan pada pretest dan posttes adalah soal pilihan ganda dan essay. Dalam Penelitian iniakan menggunakan instrument berupa tes tertulis, selain tes juga digunakan lembar observasi. Lebih rinci dijelaskan sebagai berikut:

Bentuk tes yang akan digunakan adalah tes pilihan ganda dan essay yang akan diberikan sebelum dan sesudah kegiatan pembelajaran selesai. Tes akan dikembangkan oleh peneliti yang mengacu pada indikator materi yang terkait, dengan soal pilihan ganda terdiri dari 25 butir soal dengan alternatif pilihan jawaban a, b, c, d, dan e, yang disusun berdasarkan kisi-kisi materi. Soal pilihan ganda digunakan untuk mengukur kemampuan C1 (kemampuan mengingat), C2 (kemampuan memahami), C3 (kemampuan menerapkan), dan C4 (kemampuan menganalisis). Sebelum soal-soal digunakan, akan dilakukan uji coba terlebih dahulu untuk mengetahui apakah sudah layak digunakan atau tidak. Oleh karena itu perlu dilakukan uji validitas, uji reliabilitas, daya pembeda, dan tingkat kesukaran soal.

Uji validitas suatu instrumen menunjukkan tingkat ketepatan suatu instrumen untuk mengukur apa yang harus diukur. Sebuah data atau informasi dapat dikatakan valid apabila sesuai dengan data yang sebenarnya (Nurman, M. 2015). Untuk menghitung tingkat validitas instrumen peneliti menggunakan rumus korelasi product-moment dengan angka kasar, yaitu:

$$
r_{x y}=\frac{N \sum x y-\left(\sum x\right)\left(\sum y\right)}{\sqrt{\left\{N \sum x^{2}-\left(\sum x\right)^{2}\right\}\left\{N \sum y^{2}-\left(\sum y\right)^{2}\right\}}}
$$

$$
\begin{array}{ll}
\text { Keterangan: } \\
N & \text { : Jumlah responden } \\
x & : \text { Nilai pembanding } \\
y & : \text { Nilai yang dicari validitasnya } \\
r_{\mathrm{xy}} & : \text { koefisien validitas (Arikunto, S. 2011). }
\end{array}
$$

Bila suatu alat pengukur dipakai dua kali untuk mengukur gejala yang sama dan hasil pengukuran yang diperoleh relatif konsisten, maka alat pengukur tersebut reliabel atau dipercaya (Arikunto, S. 2011). Suatu tes dapat dikatakan mempunyai taraf kepercayan yang tinggi jika hasil tes tersebut mampu memberikan hasil yang tetap. Uji reliabilitas dalam penelitian ini dilakukan dengan menggunakan rumus Alpha Cronbach, yaitu sebagai berikut:

$$
r_{11}=\left[\frac{k}{k-1}\right]\left(1 \frac{\sum_{i=1}^{n} s_{i}{ }^{2}}{s_{t}{ }^{2}}\right)
$$

$$
\begin{aligned}
& \text { Dimana : } \\
& \mathrm{r}_{11}: \text { Reliabilitas instrumen } \\
& \mathrm{k}: \text { Banyaknya butir pertanyaan atau soal } \\
& s_{i}{ }^{2}: \text { Jumlah varians butir soal ke-i } \\
& s_{t}{ }^{2}: \text { Varians total (Muhammad, Nurman, 2015). }
\end{aligned}
$$


Daya pembeda yaitu kemampuan suatu butir soal dapat membedakan antara siswa yang telah menguasai materi yang ditanyakan dan siswa yang kurang menguasai materi yang diajukan atau ditanyakan. Untuk mengetahui indeks daya pembeda soal bentuk objektif menggunakan rumus sebagai berikut:

$$
D P=\frac{2(B A-B B)}{N}
$$

Keterangan:

$$
\begin{array}{ll}
\text { DP } & \text { : Daya Pembeda Soal } \\
\text { BA } & \text { : Jumlah jawaban benar pada kelompok atas } \\
\text { BB } & \text { : Jumlah jawaban benar padakelompok bawah } \\
\text { N } & \text { : Jumlah siswa yang mengerjakan tes. }
\end{array}
$$

Adapun klasifikasinya adalah seperti tabel berikut ini (Ratnawulan, E. 2015)

Tabel 2. Klasifikasi Daya Pembeda

\begin{tabular}{cc}
\hline Skor & Klasifikasi \\
\hline $0,40-1,00$ & Soal diterima baik \\
\hline $0,30-0,39$ & Soal diterima, tetapi perlu diperbaiki \\
\hline $0,20-0,29$ & Soal diperbaiki \\
\hline $0,19-0,00$ & Soal tidak dipakai/ dihapus \\
\hline
\end{tabular}

Tingkat kesukaran soal merupakan peluang untuk menjawab benar suatu soal pada tingkat kemampuan tertentu yang dinyatakan berbentuk indeks (Ratnawulan, E. 2015). Bilangan yang menunjukkan sukar dan mudahnya suatu soal dikatakan indeks kesukaran. Besarnya indeks kesukaran antara 0,00 sampai dengan 1,0. Jika indeks kesukaran 0,0 menunjukkan soal itu terlalu sukar dan sebaliknya indeks 1,0 menunjukkan soalnya terlalu mudah (Arikunto, S. 2011). Adapun rumus yang digunakan untuk menganalisis tingkat kesukaran soal objektif adalah sebagai berikut:

$$
P=\frac{B}{J S}
$$

Keterangan:

$\mathrm{P} \quad$ : Indeks kesukaran

B : Jumlah siswa yang menjawab soal benar

JS : Jumlah seluruh siswa peserta tes.

Tabel 3. Kriteria Tingkat Kesukaran

\begin{tabular}{cc}
\hline Indeks Tingkat Kesukaran & Kategori \\
\hline $0,00-0,30$ & Soal tergolong sukar \\
\hline $0,31-0,70$ & Soal tergolong sedang \\
\hline $0,71-1,00$ & Soal tergolong mudah \\
\hline
\end{tabular}

Soal essay terdiri dari 5 soal yang disusun berdasarkan kisi-kisi soal. Soal essay digunakan untuk mengukur kemampuan yakni C4 (menganalisis), C5 (menilai), dan C6 (menciptakan).

Lembar observasi keterlaksanaan RPP dilakukan dengan observasi atau biasa disebut dengan istilah pengamatan, merupakan salah satu cara yang dilakukan oleh peneliti untuk memperoleh data dengan penelitian langsung terhadap kondisi lingkungan objek penelitian yang mendukung kegiatan penelitian dengan tujuan untuk mengetahui hasil belajar siswa (Siregar, S. 2010). Sedangkan lembar observasi merupakan alat pengamatan dan pencacatan secara sistematis terhadap gejala yang tampak oleh penelitian. 
Lembar observasi pada penelitian ini adalah lembar observasi keterlaksanaan RPP. Lembar observasi keterlaksanaan RPP berisikan tentang langkah-langkah pembelajaran sesuai RPP yang disusun sendiri oleh peneliti. Adapun langkah-langkah yang akan diamati yaitu kegiatan pendahuluan, kegiatan inti, dan kegiatan penutup. Data ini merupakan data pendukung untuk memberikan gambaran bahwa peneliti benar-benar menerapkan model pembelajaran yang isinya adalah ceklist $(\sqrt{ })$ terhadap langkah model pembelajaran kooperatif tipe jigsaw yang tertuang didalam RPP.

\section{TEMUAN DAN PEMBAHASAN}

Penelitian ini dilaksanakan di MA Darul Muhajirin Praya Tahun Pelajaran 2018/2019 sebanyak 4 kali pertemuan diantaranya 1 kali pertemuan untuk pretes, 2 kali pertemuan untuk penggunaan model pembelajaran tipe jigsaw dan 1 kali pertemuan untuk memberikan Postest. Tujuan penelitian ini untuk menguji seberapa pengaruh model pembelajaran koopeatif tipe jigsaw terhadap hasil belajar kognitif siswa pada materi Hukum Newton kelas X IPA 2 (kelas eksperimen), agar terciptanya proses pembelajaran yang efektif dan efisien serta mudah untuk dipraktekkan secara langsung kepada peserta didik supaya lebih memahami materi yang diajarkan. Adapun data-data yang dikumpulkan antara lain:

Perangkat dan instrumen yang digunakan dalam penelitian, sebelum digunakan telah dianalisis dan ditelaah atau divalidasi terlebih dahulu, baik secara kuantitatif maupun kualitatif. Validasi kualitatif atau kuantitatif dilakukan oleh pakar atau dosen pembimbing yang ahli pada bidang tersebut. Berikut disajikan tabel hasil validasi kualitatif perangkat penelitian dan instrumen.

Tabel 4. Hasil Validasi Perangkat dan Instrumen

\begin{tabular}{cccc}
\hline No & Perangkat /instrument & Nilai & Kategori \\
\hline 1 & RPP kelas Eksperimen & 4,0 & Baik \\
\hline 2 & RPP kelas Kontrol & 4,0 & Baik \\
\hline 3 & LKPD Kelas Ekperimen & 3,9 & Baik \\
\hline 4 & LKPD Kelas Kontrol & 3,9 & Baik \\
\hline 5 & Instrumen Hasil Belajar & 4,12 & Baik \\
\hline
\end{tabular}

Berdasarkan hasil validasi pada tabel di atas rata-rata secara umum dikatakan baik karena pada masing-masing perangkat memperoleh nilai di atas rata-rata. Analisis secara kuantitatif uji instrumen hasil belajar dilakukan validasi terlebih dahulu oleh dosen ahli. Hasil validasi kuantitatif secara singkat dapat dilihat pada tabel di bawah ini.

Tabel 5. Analisis Kuantitatif untuk Instrumen Hasil Belajar

\begin{tabular}{lll}
\hline No & \multicolumn{1}{c}{ Uji Instrument Hasil Belajar } & \multicolumn{1}{c}{ Klasifikasi } \\
\hline 1 & Uji Validitas & Baik \\
\hline 2 & Uji Reliabilitas & Tinggi \\
\hline 3 & Daya Pembeda & $\begin{array}{l}\text { Soal diterima baik, soal diterima, tapi perlu } \\
\text { diperbaiki dan soal diperbaiki }\end{array}$ \\
\hline 4 & Tingkat Kesukaran & Sulit dan mudah \\
\hline
\end{tabular}


Instrumen yang digunakan pada penelitian ini adalah instrument tes, yaitu menyelesaikan soal fisika yang terdiri dari 30 butir soal yang berbentuk pilihan ganda 25 soal dan uraian 5 soal yang sudah teruji karakteristiknya baik, validitas ahli, reliabilitas, daya pembeda, dan tingkat kesukaran seperti tabel diatas.

Hasil ketuntasan belajar kognitif siswa dapat dilihat dari hasil pretes (tes awal) dan posttest (tes akhir) menggunakan soal pilihan ganda dan essay. Hasil belajara kognitif pretes dapat dilihat pada tabel dibawah ini.

Tabel 6. Data Hasil Belajar Pretest Kelas Eksperimen dan Kelas Kontrol

\begin{tabular}{cccccc}
\hline Kelas & $\begin{array}{c}\text { Jumlah } \\
\text { siswa }\end{array}$ & $\begin{array}{c}\text { Nilai } \\
\text { Tertinggi }\end{array}$ & $\begin{array}{c}\text { Nilai } \\
\text { Terendah }\end{array}$ & Rata-rata & $\begin{array}{c}\text { Standar } \\
\text { Deviasi }\end{array}$ \\
\hline Ekperimen & 30 & 55 & 15 & 31,06 & 11,14 \\
\hline Kontrol & 30 & 52 & 11 & 28 & 10,71 \\
\hline
\end{tabular}

Dari data tabel di atas pada kelas eksperimen mendapat nilai tertinggi 55 dan nilai terendah 15 dan hasil rata-rata 31,06 dengan nilai standar deviasi 11,14. Sedangkan pada kelas kontrol mendapatkan nilai tertinggi 52 dan nilai terendah 11 dan nilai rata-rata 28 dengan nilai standar deviasi 10,71. Untuk data hasil posttest dapat dilihat pada tabel berikut.

Tabel 7. Data Hasil Belajar posttest Kelas KEsperimen dan Kelas Kontrol

\begin{tabular}{cccccc}
\hline Kelas & $\begin{array}{c}\text { Jumlah } \\
\text { siswa }\end{array}$ & $\begin{array}{c}\text { Nilai } \\
\text { Tertinggi }\end{array}$ & $\begin{array}{c}\text { Nilai } \\
\text { Terendah }\end{array}$ & Rata-rata & $\begin{array}{c}\text { Standar } \\
\text { Deviasi }\end{array}$ \\
\hline Ekperimen & 30 & 91 & 51 & 73 & 10,22 \\
\hline Kontrol & 30 & 87 & 45 & 61,2 & 11,02 \\
\hline
\end{tabular}

Berdasarkan tabel diatas dapat dilihat bahwa nilai tes akhir pada kelas eksperimen mendapatkan nilai tertinggi 91 dan nilai terendah 51 dan nilai rata-rata 73 dengan standar deviasi 10,22. Sedangkapan niai tes akhir pada kelas kontrol mendapat nilai tertinggi 87 dan nilai terendah 45 dan nilai rata-rata 61,2 dengan standar deviasi 11,02. Agar lebih jelas untuk melihat perbandingan antara nilai pretest dan posttes pada kelas kontrol maupun kelas eksperimen dapat dilihat dari grafik dibawah ini.

Nilai rata-rata pretes dan posttes kelas eksperimen dan kelas kontrol

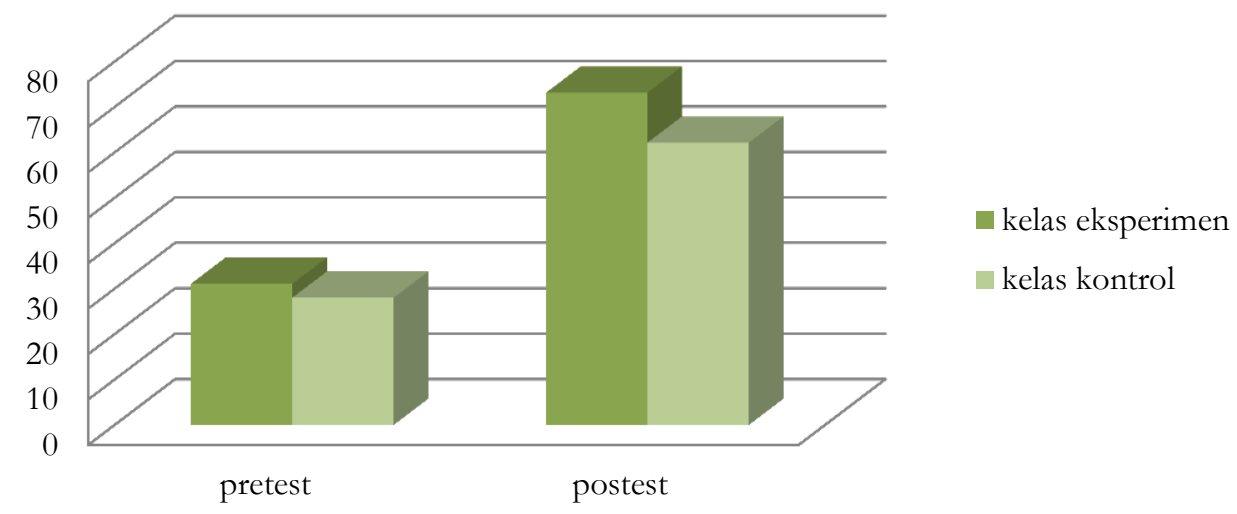

Gambar 2. Diagram nilai pretes dan posttes 
Dari gambar diagram diatas dapat dilihat ada peningkatan nilai rata-rata pretest dan posttes kelas eksperimen dan kelas kontrol, denga nilai rata-rata hasil belajar kelas eksperimen lebih tinggi dari siswa kelas kontrol. Oleh karena itu penggunaan model kooperatif tipe jigsaw dapat meningkatkan hasil belajar kognitif siswa pada pelajaran fisika.

Hasil observasi keterlaksanaan RPP untuk mengetahui terlaksananya kegiatan pembelajaran dengan baik atau tidak. Oleh karena itu dapat dilihat pada tabel dibawah ini.

Tabel 8. Tabel rangkaian hasil observasi keterlaksanaan RPP

\begin{tabular}{|c|c|c|c|c|c|}
\hline \multirow{3}{*}{ Kelas } & \multirow{3}{*}{$\begin{array}{l}\text { Aspek yang } \\
\text { dinilai }\end{array}$} & $\mathbf{R a}$ & nilai & \multirow{3}{*}{$\begin{array}{c}\text { Persentase } \\
\text { keterlaksanaan }\end{array}$} & \multirow{3}{*}{ Keterangan } \\
\hline & & \multicolumn{2}{|c|}{ Pertemuan } & & \\
\hline & & 1 & 2 & & \\
\hline \multirow{3}{*}{ Eksperimen } & Pendahuluan & 8 & 7 & \multirow{3}{*}{$90 \%$} & \multirow{3}{*}{ Sangat baik } \\
\hline & Inti & 6 & 11 & & \\
\hline & Penutup & 5 & 4 & & \\
\hline \multirow{3}{*}{ Kontrol } & Pendahuluan & 7 & 6 & \multirow{3}{*}{$80 \%$} & \multirow{3}{*}{ Sangat baik } \\
\hline & Inti & 3 & 3 & & \\
\hline & Penutup & 7 & 7 & & \\
\hline
\end{tabular}

Berdasarkan hasil analisis lembar Observasi Keterlaksanaan RPP menggunakan model kooperatif tipe jigsaw diatas, pada penelitian ini pada kelas eksperimen maupun kelas kontrol pada pertemuan pertama maupun pertemuan kedua dikategorikan sangat baik.

Analisis data pengujian hipotesis dilakukan dengan melakukan uji prayarat tentang uji normalitas, dan uji homogenitas. Uji Normalitas data bertujuan untuk mengatahui data tersebut terdistribusi normal atau tidak. Untuk uji normalitas dihitung menggunakan rumus Chi square yang hasilnya dapat dilihat pada tabel berikut

Tabel 9. Analisis Normalitas Data Nilai Pretest

\begin{tabular}{cccccc}
\hline No & Perlakuan & $\chi^{2}$ hitung & $\chi^{2}$ tabel & Kesimpulan & Keterangan \\
\hline 1 & Kelas control & 7,76 & 7,82 & $\chi^{2}$ hitung $\leq \chi^{2}$ tabel & Data Normal \\
\hline 2 & Kelas eksperimen & 4,43 & 7,82 & $\chi^{2}$ hitung $\leq \chi^{2}$ tabel & Data Normal \\
\hline
\end{tabular}

Tabel 10. Analisis Normalitas Data Nilai Posttest

\begin{tabular}{cccccc}
\hline No & Perlakuan & $\chi^{2}$ hitung & $\chi^{2}$ tabel & Kesimpulan & Keterangan \\
\hline 1 & Kelas kontrol & 6,15 & 7,82 & $\chi^{2}$ hitung $\leq \chi^{2}$ tabel & Data Normal \\
\hline 2 & Kelas eksperimen & 5,31 & 7,82 & $\chi^{2}$ hitung $\leq \chi^{2}$ tabel & Data Normal \\
\hline
\end{tabular}

Berdasarkan hasil data normalitas diatas diperoleh hasil dari nilai pretest pada kelas kontrol memperoleh nilai $\mathrm{F}_{\text {hitung }}=7,76$ dan pada kelas kontrol memperoleh nilai $\mathrm{F}_{\text {hitung }}=4,43$ jadi $\chi_{\text {hitung }}^{2}(7,76)<\chi_{\text {tabel }}^{2}(7,82)$ maka data terdistribusi normal, dan pada kelas eksperimen memperoleh nilai $\mathrm{F}_{\text {hitung }}=4,43$ jadi, $\chi_{\text {hitung }}^{2}(4,43)<\chi_{\text {tabel }}^{2}(7,82)$ maka data yang diperolah terdistribusi normal. Sedangkan pada nilai posttest pada kelas kontrol dengan $\chi_{\text {hitung }}^{2}(6,15)<\chi_{\text {tabel }}^{2}(7,82)$ maka data tersebut terdistribusi normal, sedangkan pada kelas eksperimen diperoleh nilai $\chi_{\text {hitung }}^{2}(2,31)<\chi_{\text {tabel }}^{2}$ $(7,82)$ maka data tersebut terdistribusi normal. 
Uji homogenitas bertujuan untuk mengetahui apakah seragam atau tidak kevariansian dari sampel yang didapatkan dari dua populasi yakni kelas ekperimen dan kontrol. Hasil uji homogenitas dapat dilihat pada tabel dibawah ini.

Tabel 11. Analisis Homogenitas

\begin{tabular}{cccccc}
\hline Data & $\begin{array}{c}\text { Variansi } \\
\text { terbesar }\end{array}$ & $\begin{array}{c}\text { Variansi } \\
\text { terkecil }\end{array}$ & $\mathbf{F}_{\text {hitung }}$ & $\mathbf{F}_{\text {tabel }}$ & Keterangan \\
\hline Pretest & 33,64 & 32,10 & 1,04 & 1,85 & Data Homogen \\
\hline Posttes & 35,53 & 30,11 & 1,18 & 1,85 & Data Homogen \\
\hline
\end{tabular}

Berdasarkan tabel diatas pada nilai pretes mendapatkan nilai variansi terbesar 33,64 dan variansi terkecil 32,10 setelah di hitung mendapatkan nilai $F_{\text {hitung }} 1,04$ dan $F_{\text {tabel }}$ 1,85. Sedangkan pada Postest mendapatkan nilai vaniansi terbesar 35,53, dan variansi terkecil 30,11, setelah dihitung mendapatkan nilai $\mathrm{F}_{\text {hitung }}$ 1,18 dan $\mathrm{F}_{\text {tabel }}$ 1,85. Dapat disimpulkan berdasarkan data diatas bahwa varians kedua data adalah homogen atau kedua data mempunyai varian yang sama.

Pada uji hipotesis ini menggunakan uji t yang dimana uji ini digunakan untuk mengetahui hipotesis yang diajukan oleh peneliti apakah dapat diterima atau tidak, untuk mengetahui apakah ada pengaruh terhadap model yang diterapkan atau tidak. Analisis yang digunakan yaitu uji t-tes dengan rumus pooled Varians. Hasil yang diperoleh dapat dilihat pada tabel dibawah ini.

Tabel 12. Analisis Uji $t$-tes

\begin{tabular}{|c|c|c|c|c|c|c|c|c|}
\hline \multirow{2}{*}{ Perlakuan } & \multirow{2}{*}{$\begin{array}{l}\text { Jumlah } \\
\text { siswa }\end{array}$} & \multirow{2}{*}{$\begin{array}{l}\text { Rata- } \\
\text { rata }\end{array}$} & \multirow{2}{*}{$\begin{array}{c}\text { Standar } \\
\text { Deviasi } \\
\left(\mathrm{s}^{2}\right)\end{array}$} & \multirow{2}{*}{ Signifikan } & \multicolumn{2}{|c|}{ Hasil } & \multirow[b]{2}{*}{ Kesimpulan } & \multirow[b]{2}{*}{ Keterangan } \\
\hline & & & & & thitung $_{\text {hith }}$ & $\mathbf{t}_{\text {tabel }}$ & & \\
\hline $\begin{array}{l}\text { Kelas } \\
\text { Kontrol }\end{array}$ & 30 & 62,13 & 121,56 & 0,05 & \multirow[b]{2}{*}{4,150} & \multirow[b]{2}{*}{2,000} & \multirow[b]{2}{*}{$t_{\text {itung }}>t_{\text {tabel }}$} & \multirow[b]{2}{*}{$\begin{array}{l}\text { Hipotesis } \\
\text { diterima }\end{array}$} \\
\hline $\begin{array}{l}\text { Kelas } \\
\text { Eksperimen }\end{array}$ & 30 & 73,13 & 104,53 & 0,05 & & & & \\
\hline
\end{tabular}

Berdasarkan data di atas untuk nilai posttest kelas kontrol yaitu nilai rata-rata diperoleh 62,13, dengan standar deviasi 121,56 dari signifikan 0,05 dengan jumlah siswa 30 orang. Sedangkan pada kelas ekperimen memperoleh nilai rata-rata 73,13, dengan standar deviasi 104,53 dari signifikan 0,05 dengan jumlah siswa yang sama yaitu 30 orang. Dapat disimpulkan dari hasil posttest kelas kontrol dan kelas eksperimen yaitu dilihat dari $t_{\text {hitung }}=4,150>t_{\text {tabel }}=2,000$.

Berdasarkan analisis data Pengujian hipotesis dilakukan menggunakan uji t dengan ketentuan kedua kelompok harus diambil dari populasi yang terdistribusi normal dan variansi yang homogen. Sebelum dilakukan uji hipotesis maka terlebih dahulu harus melakukan uji normalitas dan homogenitas data yang dimana dihitung secara manual menggunakan rumus yang sudah ditentukan.

Pengujian uji normalitas menggunakan rumus chi-kuadrat dengan membandingkan nilai posttest kedua kelas sampel dengan $\chi^{2}{ }_{\text {hitung }}<$ dari $\chi_{\text {tabel }}^{2}$ dan taraf signifikan 0,05. Kelas ekperimen mendapatkan nilai $\chi_{\text {hitung }}^{2}(5,31)<\chi_{\text {tabel }}^{2}(7,82)$ sedangkan pada kelas control didapatkan $\chi_{\text {hitung }}^{2}$ $(6,15)<\chi_{\text {tabel }}^{2}(7,82)$. Dengan demikian maka dapat disimpulkan kedua data dari masing-masing kelas terdistribusi normal.

Pengujian homogenitas data dengan menggunakan uji $\mathrm{F}$ dimana uji ini membandingkan varians terbesar dibagi dengan varians terkecil yang didapatkan pada masing-masing sampel dengan taraf signifikan 0,05, dimana kelas ekperimen memperoleh varians data 30,11, sedangkan 
kelas kontrol memperoleh varias data 35,53. Kedua data tersebut setelah dibagi maka memperoleh nilai varians data $\mathrm{F}_{\text {hitung }} 1,18$ yang akan dibandingkan dengan $\mathrm{F}_{\text {tabel }} 1,85$, jadi $\mathrm{F}_{\text {hitung }} 1,18<\mathrm{F}_{\text {tabel }} 1,85$. Maka dapat disimpulkan varians data mendapatkan varians yang homogen. Setelah mendapatkan data terdistribusi normal dan varians data homogen dapat dilanjutkan dengan uji hipotesis.

Hasil perhitungan uji hipotesis dengan menggunakan uji $\mathrm{t}$ menunjukan bahwa $\mathrm{t}_{\text {hitung }}=$ $4,150 \geq \mathrm{t}_{\mathrm{tabel}}=2,000$. Maka artinya bahwa hasil belajar kognitif menggunakan model pembelajaran kooperatif tipe jigsaw dapat meningkatkan hasil belajar kognitif siswa yang dilihat dari nilai posttest kedua kelas tersebut, selain itu, berdasarkan hasil pengamatan yang telah dilaksanakan selama melakukan penelitian kualitas pembelajaran didalam kelas terbilang meningkat dengan baik dan semangat untuk belajar karena mendapatkan perlakuan yang baru, sehingga dapat disimpulkan bahwa terdapat perbedaan hasil belajar kognitif yang signifikan antara kelas eksperimen yang menggunakan model pembelajaran kooperatif tipe jigsaw dengan kelas kontrol menggunakan model pembelajaran konvensional pada materi hukum newton kelas X di MA darul muhajirin Praya Tahun Ajaran 2018/2019.

Pembelajaran kooperatif adalah salah satu sistem pengajaran yang memberikan kebebasan berpedapat dan bekerjasama dengan antar siswa dalam menyelesaikan tugas-tugas yang terstruktur (Samaela, Jamhari and Nengah, 2017). Model pembelajaran kooperatif tipe jigsaw adalah proses pembelajaran yang menuntut siswa untuk belajar dan bekerja sama dalam sebuah kelompokkelompok kecil dimana setiap siswa bisa berpartisipasi dalam tugas-tugas kolektif yang sudah ditentukan, selain itu pembelajaran kooperatif ini juga siswa dihadapkan pada proses berpikir teman sebaya, melatih mereka untuk berani berpendapat dan bertanggung jawab atas materi yang ditentukan (Susilo, Sunarno and Suparmi, 2016). Keterkaitan antara model pembelajaran tipe jigsaw dengan perkembangan siswa sangat cocok. untuk diterapkan, karena dapat terlihat perkembangan siswa mampu berpikir lebih aktif, mampu bertinteraksi dengan teman sebaya dan mampu melatih siswa untuk bertanggung jawab tentang apa yang didapatkan dari hasil diskusi kepada teman yang lain. Sehingga model pembelajaran kooperatif tipe jigsaw mampu diterapkan pada tingkat SMP dan SMA.

Berdasarkan penjelasan di atas dapat dijelaskan bahwa penggunaan model pembelajaran tipe jigsaw ini dapat meningkatkan hasil belajar kognitif siswa. Berdasarkan penelitian Nurhadi, N (2019) terbukti bahwa penerapan model pembelajaran Cooperative learning tipe jigsaw dapat meningkatkan hasil belajar siswa. Hal ini sejalan dengan penelitian yang dilakukan oleh Suharsono bahwa menggunakan model pembelajaran jigsaw lebih baik dari model STAD dan metode jigsaw dapat meningkatkan prestasi belajar pada mata pelajaran pendidikan kewarganegaraan (Suharsono, 2015), dan sejalan juga dengan hasil penelitian dari zulfikar Muhammad yang berjudul pengaruh metode pembelajaran kooperatif tipe jigsaw terhadap motivasi dan hasil belajar mahasiswa (Muhammad, 2018).

Menggunakan model pembelajaran kooperatif tipe jigsaw ini bukan hanya membuat proses pembelajaran menjadi berbeda dengan model pembelajaran lain, tetapi model ini juga membantu siswa untuk lebih mencari sendiri informasi atau pengetahuan tentang pelajaran yang dimana mata pelajaran fisika dikenal sulit untuk difahami. Adapun kelebihan model pembelajaran kooperatif tipe jigsaw adalah mampu meningkatkan hasil belajar siswa, mampu memotivasi belajar siswa yang sesuai dengan penelitian yang mengatakan bahwa pada kelas eksperimen yang menggunakan model pembelajaran kooperatif tipe jigsaw terjadi peningkatan motivasi yang lebih baik dari pada kelas kontrol yang belajar menggunakan pembelajaran konvensional (Juwaeriah, Muhyani and Ikhtiono, 2018). Kelebihan selanjutnya yaitu, interaksi antar teman sebaya ditekankan untuk bekerja sama dalam kelompok dan aktif dalam berpendapat. 


\section{SIMPULAN}

Berdasarkan rumusan masalah dan hasil analisis data yang telah diuraikan pada pembahasan, maka terbukti bahwa ada pengaruh model pembelajaran kooperatif tipe jigsaw terhadap hasil belajar siswa pada pokok materi hukum newton kelas X di MA Darul Muhajirin Praya tahun pelajaran 2018/2019. Penggunaan model pembelajaraan kooperatif tipe jigsaw pada kelas eksperimen memperoleh hasil belajar yang lebih baik dari pada hasil belajar siswa yang menggunakan model pembelajaran konvensional pada kelas kontrol. Hal ini dapat dibuktikan dengan uji hipotesis t-tes memperoleh nilai $t_{\text {hitung }}=4,150>t_{\text {tabel }}=2,000$. Sehingga dapat disimpulkan bahwa terdapat perbedaan hasil belajar kognitif yang signifikan antara kelas eksperimen yang menggunakan model pembelajaran kooperatif tipe jigsaw dengan kelas kontrol yang menggunakan model pembelajaran konvensional pada materi hukum newton kelas X di MA darul muhajirin Praya Tahun Ajaran 2018/2019.

\section{REFERENSI}

Bahtiar. (2015). Strategi Belajar Mengajar Sains (IPA). Mataram: CV Sanabil.

Bambang prasetyo. (2016). Metode penelitian kuantitatif. Depok: PT Raha Gravindo Persada.

Eris Ratnawulan. (2015). Evaluasi Pembelajaran. Bandung: CV Pustaka Setia.

Gunawan, I. (2014). Revisi Taksonomi Bloom Ranah Kognitif: Kerangka Landasan Untuk Pembelajaran, Pengajaran, Dan Asesmen, Jurnal Pendidikan Dasar Dan Pembelajaran. (1), 98-117.

Ifa, M. (2013). Penerapan Model Pembelajaran Kooperatif Tipe Jigsaw untuk Meningkatkan Hasil Belajar Siswa Kelas X SMK Negeri 3 Boyolangu pada Standar Kompetensi Menerapkan Keselamatan dan Kesehatan Kerja (K3). Jurnal Pendidikan Teknik Elektro, 2(2), 715-722

Juwaeriah, S., Muhyani, M. and Ikhtiono, G. (2018). Pengaruh Model Pembelajaran Kooperatif Tipe Jigsaw Terhadap Motivasi Belajar Dan Hasil Belajar Siswa Pada Mata Pelajaran Matematika', Attadib: Journal of Elementary Education, 1(2), 78. doi: 10.32507/attadib.v1i2.24.

Muhammad Nurman. (20115). Evaluasi Pendidikan, Mataram: CV. Sanabil.

Nurhadi, N. (2019). Penerapan Model Pembelajaran Cooperative Learning Tipe Jigsaw Untuk Meningkatkan Hasil Belajar Fisika Siswa Kelas XII IPA 3 SMA Negeri 3 Bengkalis. Journal of Natural Science and Integration, 2(1), 76-84.

Nurhaeni, Y. (2011). Meningkatkan Pemahaman Siswa Pada Konsep Listrik Melalui Pembelajaran Kooperatif Tipe Jigsaw Pada Siswa Kelas Ix Smpn 43 Bandung', Jurnal Penelitian Pendidikan, 12(1), 77-89.

Oktafiani, Z. (2018). Meningkatkan Aktivitas dan Kemampuan Kognitif dengan Model Pembelajaran Kooperatif Tipe Jigsaw pada Siswa Kelas X SMA Negeri 1 Wedung Tahun Pelajaran 2016/2017. JP3 (Jurnal Pendidikan dan Profesi Pendidik), 3(1)., 59-73.

Pohan, D., \& Simamora, P. (2014). Pengaruh Model Pembelajaran Kooperatif Tipe Jigsaw Berbasis Macromedia Flash Terhadap Hasil Belajar Siswa Pada Materi Pokok Hukumhukum Newton. INPAFI (Inovasi Pembelajaran Fisika), 2(3).45-53

Samaela, D. P., Jamhari, M. and Nengah, I. (2017). Pengaruh Model Pembelajaran Kooperatif Tipe Jigsaw II dan Teknik Peta Pikiran Terhadap Hasil Belajar Siswa Kelas X SMA Negeri Poso Pada Mata Pelajaran Biologi', e-Journal Mitra Sains, 5, 48-57.

Sugiyono. (2010). Metodelogi Penelitian Kuantitatif dan R \& D. Bandung: Alfabeta. 
Suharsimi Arikunto. (2013). Prosedur Penelitian Suatu Pendekatan Praktik. Jakarta: Rineka Cipta.

Suharsono. (2015). Pengaruh Model Pembelajaran Kooperatif Jigsaw Dan Stad (Student Team Achievement Division) Terhadap Prestasi Belajar Pendidikan, Jurnal Penelitian dan Pendidikan IPS (JPPI), 9(3), 1295-1305.

Susilo, F., Sunarno, W. and Suparmi. (2016). Pembelajaran Fisika Menggunakan Model Jigsaw Dan Gi (Group Investigation) Ditinjau Dari Kreativitas. Jurnal Inkuiri, 5(3), 40-48. Available at: http://jurnal.fkip.uns.ac.id/index.php/sains.

Syarifuddin, A. (2011). Model Pembelajaran Cooperative Learning Tipe Jigsaw Dalam Pembelajaran, Ta'dib, 16(02), 209-226.

Syofian Siregar. (2010). Statistika Deskriptif untuk Penelitian. Jakarta: PT Raja Grafindo Persada.

Trisianawati, E., Djudin, T., \& Setiawan, R. (2016). Pengaruh model pembelajaran kooperatif tipe jigsaw terhadap hasil belajar siswa pada materi vektor di kelas X SMA Negeri 1 Sanggau Ledo. Jurnal Penelitian Fisika dan Aplikasinya (JPFA), 6(2), 51-60. 